\title{
OPTIMIZING CHILDREN GROSS MOTORIC SKILL BY YOGA ASANA PRACTICE IN COVID-19 PANDEMIC
}

\author{
Ni Putu Eni Astuti \\ STKIP Suar Bangli, Bali, Indonesia \\ Putu.eniastuti@gmail.com
}

\begin{abstract}
This paper describes the activity of yoga asana in optimizing children gross motoric skill. It is a qualitative descriptive study involving early age children in Buahan Village, Bali in Yoga Asana as an activity to improve physical activity in covid-19 pandemic. The data source used primary and secondary data sources. The primary data source was collected from the result of observation and interview regarding to Asana's systematic and sequences. The secondary data was collected from yoga literature review and research review, especially yoga for the children. Data analysis used content analysis about child muscle activity in every Asana in every steps of Yoga Asana. The finding showed that Yoga Asana activity consisted of five steps namely asana stretching, the core of asana, relaxation, pranayama, and simple meditation. From these sequences, as ana stretching and the core of asana could the most optimize the child gross motoric performance by (1) improving child movement range through joint movement, (2) improving physical activity performance by preparing muscle, train muscular flexibility behind the knee, strengthening muscles of arms, back, stomach, shoulders and legs, (3) improving flexibility and align the spinal nerves, (4) improving movement coordination of the child body.
\end{abstract}

Keywords: gross motoric, yoga asana, covid-19 pandemic

\section{OPTIMALISASI KETERAMPILAN FISIK MOTORIK KASAR ANAK DENGAN LATIHAN YOGA ASANA DITENGAH PANDEMI COVID-19}

\begin{abstract}
ABSTRAK
Tulisan ini bertujuan untuk menggambarkan kegiatan yoga asana didalam mengoptimalkan keterampilan motorik kasar anak. Penelitian ini merupakan penelitian deskriptif kualitatif yang melibatkan anak-anak usia dini di desa Buahan Tabanan, Bali dalam kegiatan yoga asana sebagai kegiatan untuk meningkatkan aktifitas fisik pada masa pandemi covid-19. Sumber data menggunakan sumber data primer dan sekunder. Sumber data primer diperoleh dari hasil observasi dan wawancara mengenai sistematika dan rangkaian asana dan sumber data sekunder diperoleh melalui telaah pustaka yoga dan kajian penelitian khususnya yoga anak. Analisis data menggunakan analisis isi mengenai aktifitas otot anak pada tiap asana dalam setiap tahapan yoga asana. Hasil penelitian menunjukkan bahwa kegiatan yoga asana terdiri dari lima tahapan mulai dari asana peregangan, inti, pengendoran, pranayama, dan meditasi sederhana. Dari rangkaian tersebut, asana peregangan dan asana inti dapat paling mengotimalkan kinerja motorik kasar anak dengan (1) meningkatkan rentang gerak anak melalui gerakan sendi, (2) meningkatkan kinerja aktivitas fisik dengan mempersiapkan otot, melatih kelenturan otot di belakang lutut, memperkuat otot lengan, punggung, perut, bahu dan kaki. (3) meningkatkan kelenturan dan menyelaraskan urat-urat syaraf tulang belakang, (4) meningkatkan koordinasi gerak anggota tubuh anak.
\end{abstract}

Kata Kunci: motorik kasar, yoga asana, pandemi covid-19

\begin{tabular}{|c|c|c|}
\hline Submitted & Accepted & Published \\
\hline 01 Juni 2020 & 04 Agustus 2020 & 24 September 2020 \\
\hline
\end{tabular}

\begin{tabular}{|l|l|l|l|l}
\hline Citation & $:$ & Astuti, N.P.E. (2020). Optimizing Children Gross Motoric Skill By Yoga Asana Practice In Covid-19 Pandemic. Jurnal \\
\hline
\end{tabular}
PAJAR (Pendidikan dan Pengajaran), 4(5), 926-936. DOI : http://dx.doi.org/10.33578/pjr.v4i5.8032.

\section{PENDAHULUAN}

World Health Organization (WHO) telah menetapkan virus Corona atau COVID-19 sebagai pandemi karena telah menyebar ke lebih dari 100 negara di dunia (Widyaningrum, Gita Laras. 2020). WHO sendiri mendefinisikan pandemi sebagai situasi ketika terdapat kemungkinan populasi seluruh dunia akan terkena infeksi dan sebagian dari mereka berpotensi jatuh sakit.
Dikutip dari Kamus Besar Bahasa Indonesia (KBBI), pandemi adalah wabah yang berjangkit serempak di mana-mana atau meliputi geografi yang luas.

Dampak pandemi COVID-19 menyentuh ke berbagai sektor kehidupan masyarakat dunia seperti ekonomi, sosial, termasuk juga pendidikan. Organisasi Pendidikan, Keilmuan, dan 
Kebudayaan Perserikatan Bangsa-Bangsa atau United Nations Educational, Scientific and Cultural Organization (UNESCO) menyatakan bahwa, wabah virus corona telah berdampak terhadap sektor pendidikan. Hampir 300 juta siswa terganggu kegiatan sekolahnya di seluruh dunia dan terancam berdampak pada hak-hak pendidikan mereka. Di Indonesia sendiri, dunia pendidikan juga ikut merasakan dampaknya. Dampak yang paling dirasakan oleh peserta didik di instansi penyelenggara pelayanan pendidikan, seperti sekolah disemua tingkatan, lembaga pendidikan non formal hingga perguruan tinggi.

Terdapat beberapa kebijakan pemerintah di sektor pendidikan pada masa darurat covid-19 ini di negara Indonesia. Salah satu kebijakan yang merujuk pada Surat Edaran Mendikbud Nomor 3 Tahun 2020 tentang Pencegahan COVID-19 pada Satuan Pendidikan, dan Nomor 36962/MPK.A/HK/2020, yang menyatakan bahwa kegiatan belajar mengajar dilakukan secara daring dalam rangka pencegahan penyebaran Corona Virus Disease (COVID-19). Sejumlah pemerintah daerah pun sudah meliburkan sekolah untuk mengantisipasi penyebaran COVID-19. Sebagian solusinya, pembelajaran di sekolah diganti dengan pembelajaran dalam jaringan (daring), atau akrab disebut online.

Sekolah melalui para guru menyiapkan dan menggunakan berbagai platform pembelajaran online untuk memudahkan siswa memahami materi sesuai kurikulum lengkap dengan evaluasinya. Sekolah mewajibkan siswa dengan sejumlah kegiatan mulai dari membaca materi dengan pemberian modul atau bahan ajar yang lainnya, penilaian sumatif berkala, atau beragamnya tugas dengan batasan waktu tertentu. Tentunya pembelajaran online ini sangat memerlukan bantuan orang tua, khususnya siswa yang masih memerlukan bimbingan terutama yang berusia sekolah dasar dan anak usia dini.

Pada masa pandemi ini, didalam pembelajaran online orang tua beralih peran menggantikan guru untuk menjelaskan materi yang belum dipahami anak. Disisi lain, orang tua terfokus untuk mendorong anak belajar dan tidak jarang mengambil peran menyelesaikan segala tugas anak. Hal ini juga memaksa anak beradaptasi dengan gaya mengajar orang tua yang berbeda dengan guru mereka di sekolah. Orang tua terkesan memberi sedikit perhatian mereka untuk mengajak anak menyeimbangkan aktifitas akademik dengan aktifitas fisik selama mereka "di rumah aja".

Aktifitas fisik merupakan kegiatan yang tidak dapat disampingkan dengan aktifitas akademik, terlebih untuk anak-anak. Aktivitas fisik merupakan kegiatan yang penting dilakukan oleh anak-anak. Aktifitas fisik yang tepat dan sesuai periode diharapkan akan berdampak pada pertumbuhan fisik dan perkembangan emosi optimal (Burhaein, Erick. 2017). Aktivitas jasmani walaupun itu hanya olahraga yang sifat nya tidak terstruktur seperi jalan, bersepeda, bermain lompat tali dan berlari-larian dengan melakukan aktivitas gerak seperti itu motorik anak akan lebih baik serta tumbuh kembang mereka menjadi optimal (Rubiyatno. 2014). Aktivitas fisik yang dilakukan dapat meningkatkan fungsi kognitifnya antara lain meningkatkan daya ingat anak, fokus dan perhatian, serta kemampuan untuk menerima informasi dan memecahkan masalah. Anak usia sekolah disarankan untuk melakukan aktifitas fsik satu hingga dua jam sehari. Jenis kegiatan fisik yang dilakukan tidak harus olah raga, bermain bersama teman sambil berlari juga dapat dikatakan kegiatan fisik. Hal ini juga akan memberikan manfaat terhadap kesehatannya baik untuk kesehatan jantung, menghindari obesitas, serta bermanfaat bagi kesehatan anak (nutriclub.co.id)

Aktifitas fisik adalah setiap gerakan tubuh yang dapat meningkatkan pengeluaran tenaga atau energi. Ada 3 komponen utama dalam aktifitas fisik yaitu aktifitas/ kegiatan sehari-hari, latihan fisik dan olahraga (bantul2, 2018). Aktifitas atau kegiatan sehari-hari dapat berupa membersihkan rumah, mencuci, menyetrika, memasak, berkebun, naik-turun tangga, dll. Latihan fisik adalah semua bentuk aktifitas fisik yang dilakukan secara terstruktur dan terencana, dengan tujuan untuk meningkatkan kebugaran jasmani, misalnya: jalan kaki, jogging, sit-up/ push-up, peregangan, senam aerobik, bersepeda dan sebagainya. Sedangkan olahraga adalah salah satu bentuk aktifitas fisik 
yang dilakukan secara terstruktur, terencana dan berkesinambungan dengan mengikuti aturanaturan tertentu dan bertujuan untuk meningkatkan kebugaran jasmani dan prestasi.

Yoga adalah salah satu jenis olahraga yang pamornya terus menanjak di mata publik dalam beberapa tahun belakangan. Yoga adalah sebuah aktivitas fisik yang melibatkan meditasi dengan teknik peregangan, pernapasan, keseimbangan, dan kelenturan tubuh untuk mencapai keselarasan dan harmoni antara emosi, jiwa, mental, spiritualitas, dan tubuh (Kompas.com). Yoga is more than just a workout-it's actually a combination of four components: postures (like tree pose), breathing practices, deep relaxation, and meditation that can transform your health on many different levels (Harvard Health Publishing). Gerakangerakan yoga dapat membantu kekuatan fisik anak, dari otot, tulang hingga mobilitas gerak motorik kasar dan fleksibilitasnya (Puri, 2015).

Perkembangan fisik motorik anak merupakan proses perkembangan yang berkesinambungan, terjadi secara signifikan pada pembentukan tulang, tumbuh kembang gerakan otot-otot dan saraf sesuai dengan rentang usianya yang berpengaruh terhadap keterampilan gerak anak. Perkembangan fisik motorik terbagi menjadi 2 yakni perkembangan motorik kasar dan perkembangan motorik halus. Permendikbud No. 137 Tahun 2014 tentang fisikmotorik sebagaimana dimaksud pada ayat (1), yaitu a. motorik kasar, mencakup kemampuan gerakan tubuh secara terkoordinasi, lentur, seimbang, lincah, lokomotor, non-lokomotor, dan mengikuti aturan; b. motorik halus, mencakup kemampuan dan kelenturan menggunakan jari dan alat untuk mengeksplorasi dan mengekspresikan diri dalam berbagai bentuk.

Motorik kasar adalah aktivitas dengan menggunakan otot-otot besar, meliputi gerak dasar lokomotor, non lokomotor dan manipulatif. Gerakan motorik kasar merupakan bagian dari aktivitas yang mencakup keterampilan otot-otot besar, gerakan ini lebih menuntut kekuatan fisik dan keseimbangan (Samsudin, 2008). Motorik kasar berkaitan dengan gerak, dimana gerakan yang dihasilkan membutuhkan koordinasi bagian tubuh, otot, dan syaraf (Sujiono, 2010). Jadi, keterampilan motorik kasar sangat berhubungan dengan otot, syaraf, dangan koordinasi dan keseimbangan tubuh, yang juga terdapat didalam yoga khususnya hatha yoga yang memfokuskan penyatuan diri dengan tuhan melalui penguasaan tubuh dan napas (Somvir, 2002). Jadi, dalam penelitian ini, peneliti ingin mengetahui bagaimana kegiatan yoga didalam optimalisasi keterampilan fisik motorik anak.

\section{METODE PENELITIAN}

Penelitian ini merupakan penelitian deskriptif kualitatif. Penelitian deskriptif kualitatif ini merupakan pendekatan ilmiah dan mengandalkan manusia sebagai instrumen penelitian (Creswell, 2015). Data yang terkumpul berbentuk narasi, kata-kata, dan gambar di rangkai menjadi sebuah kesimpulan yang berbentuk deskripsi.

Dalam penelitian ini yang menjadi subjek penelitian adalah anak usia dini yang berusia 6 tahun. Jika ditinjau dari usia maka dari usia 0 hingga anak berusia 6 tahun berada pada kategori anak usia dini (Undang-undang Sisdiknas, 2003). Terdapat 3 orang anak yang menjadi subjek didalam penelitian ini yang mengikuti kegiatan yoga asana ditengah pandemi covid-19, yang diadakan oleh dosen PGSD STKIP Suar Bangli di Desa Buahan Tabanan, Bali.

Sumber data menggunakan sumber data primer dan sekunder. Sumber data primer diperoleh dari hasil observasi dan wawancara mengenai sistematika dan rangkaian asana. Sumber data sekunder diperoleh melalui telaah pustaka yoga untuk mengetahui keterampilan motorik kasar anak dalam tiap asana, serta kajian penelitian khususnya tentang yoga anak. Teknik observasi yang digunakan didalam penelitian ini adalah observasi partisipasi lengkap, dimana keterlibatan peneliti sangat tinggi didalam aktivitas yang diteliti sehingga peneliti tidak terlihat melakukan penelitian, (Sugiyono, 2006). Metode pengumpulan data observasi menggunakan kuesioner, dan wawancara menggunakan teknik wawancara terstruktur dengan pedoman wawancara. Kuesioner dan pedoman wawancara 
ini mengukur kegiatan yoga dalam kelompok- kelompok asana seperti yang nampak pada tabel 1.

Tabel 1. Indikator Kegiatan Yoga Asana Dalam Kuesioner Penelitian

\begin{tabular}{|c|c|c|}
\hline $\begin{array}{l}\text { Kelompok } \\
\text { Asana }\end{array}$ & Indikator Motorik Kasar & Asana \\
\hline \multirow[t]{20}{*}{ Peregangan } & Peregangan leher & Menekuk leher \\
\hline & & Memutar persendian leher \\
\hline & Peregangan Bahu & Penekukan siku \\
\hline & & Memutar persendian bahu \\
\hline & Gerakan lutut & Menekuk lutut \\
\hline & & Kupu-kupu \\
\hline & & $\begin{array}{l}\text { Peregangan lutut dengan menarik salah } \\
\text { satu lutut dl posisi duduk }\end{array}$ \\
\hline & Peregangan Kaki & Penekukan jari kaki \\
\hline & & Penekukan pergelangan kaki \\
\hline & & Memutar persendian kaki \\
\hline & Peregangan Tulang Belakang & Baling-baling \\
\hline & (posisi duduk) & Parivrtti janu sirsasana \\
\hline & & Yoga Mudra \\
\hline & Peregangan Tulang Belakang & Kati Cakrasana \\
\hline & (posisi berdiri) & Hasta uttanasana \\
\hline & & Tiryaka tadasana \\
\hline & & Utthita Lolasana \\
\hline & & Meru Prsthasana \\
\hline & & Dwikonasana \\
\hline & & Trikonasana \\
\hline \multirow[t]{12}{*}{ Asana inti } & Suryanamaskara & Pranamasana \\
\hline & & Hasta Uttanasana \\
\hline & & Padahastasana \\
\hline & & Asva Sancalanasana \\
\hline & & Parvatasana \\
\hline & & Astangga Namaskara \\
\hline & & Bhujangasana \\
\hline & & Parvatasana \\
\hline & & Asva Sancalanasana \\
\hline & & Padahastasana \\
\hline & & Hasta Uttanasana \\
\hline & & Pranamasana \\
\hline Asanas & & Advasana \\
\hline \multirow[t]{2}{*}{ Pendinginan } & & Savasana \\
\hline & & Makarasana \\
\hline Asana & & Bersila \\
\hline \multicolumn{3}{|l|}{ Pranayama } \\
\hline Asana & & Cimudrasana \\
\hline Meditasi & & \\
\hline
\end{tabular}

Analisis data dilakukan secara kualitatif yaitu dengan melakukan analisis terhadap sistematika yoga asana dan gerakan yoga asana yang berhubungan dengan keterampilan motorik kasar anak. Hasil analisis ini dipadukan dengan teknik dan manfaat tiap asana yang diperoleh dari mengkaji pustaka yoga. Gerakan yoga asana yang terdapat pada masing-masing sitematika yoga 
asana kemudian dideskripsikan dari cara melakukan gerakan sehingga dapat digambarkan keterampilan motorik kasar yang terkandung didalamnya.

\section{HASIL DAN PEMBAHASAN}

Latihan yoga asana di dalam penelitian ini menggunakan sistematika. Sistematika latihan yoga asana ini melalui lima tahap, mulai dari asana peregangan, inti, dan pengendoran, kemudian dilanjutkan dengan pranayama dan meditasi. Sebelum memulai asana, anak-anak diajak untuk mengaawali dengan berdoa, begitu juga diakhir kegiatan. Sistematika latihan yoga asana tergambar seperti yang nampak pada gambar 1 .

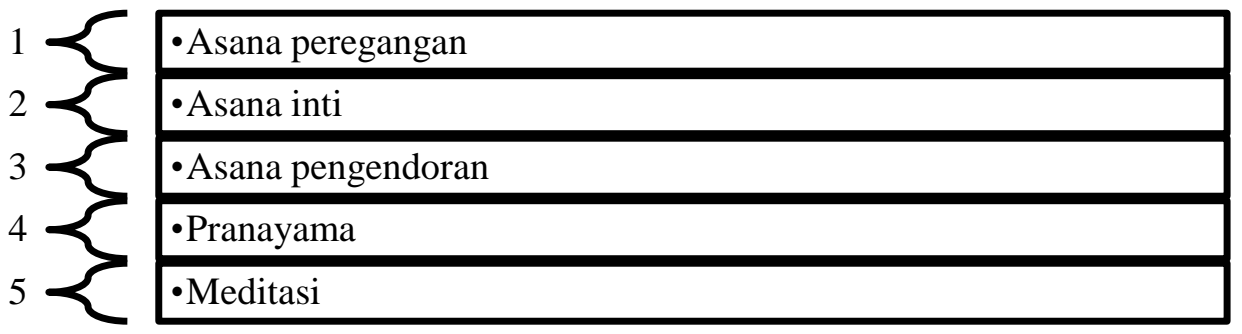

Gambar 1. Sistematika Latihan Yoga Asana

Asana adalah suatu keadaan tubuh dalam kondisi tetap mantap, tenang, santai, dan nyaman baik secara fisik maupun mental (Sarasvati, 2002). Bagi anak-anak yang sedang dalam masa pertumbuhan yoga asana sangat baik dilakukan karena melatih fisik dan mental secara holistik dimana yoga mempengaruhi fungsi susunan syaraf, kelenjar-kelenjar endokrin, semua organ dapat terlibat didalamnya diantaranya otot, tulang, syaraf, kelenjar, jalan pernafasan, pembuangan dan sistem peredaran darah sebagaimana mestinya.

Di dalam asana peregangan, anak diajak untuk melakukan serangkaian gerakan peregangan yang begitu penting khususnya untuk menghindari cedera otot atau sendi. Asana peregangan juga sangat penting dilakukan agar anak siap menuju asana inti. Peregangan dilakukan mulai dari kepala, leher, bahu, pinggang, lutut, kaki, dan tulang belakang. Di dalam asana inti terdapat serangkaian asana yang wajib dilakukan. Dalam penelitian ini, gerakan surya namaskara merupakan asana wajib. Surya namaskara dilakukan menyesuaikan dengan kondisi fisik anak baik kelenturan, intensitas latihan, kenyamanan, dan juga waktu yang disediakan. Setelah menyelesaikan beberapa kali putaran suryanamaskara, anak-anak diajak untuk melakukan asana pengendoran. Asana ini bertujuan untuk mengistirahatkan anak setelah melakukan serangkaian gerakan asana inti. Setelah melakukan serangkaian latihan asana, maka dilanjutkan dengan pranayama, yakni melatih keluar masuknya napas dengan pengaturan napas. Terakhir, anak-anak diajak untuk melakukan meditasi sederhana. Meditasi dilakukan untuk melatih anak untuk menciptakan ketenangan pikiran dan tubuh yang rileks, dengan cara duduk dalam posisi silasana, memejamkan mata, dengan suasana tenang tanpa gangguan.

\section{Pembahasan}

\section{Aktivitas Motorik Kasar Dalam Asana Peregangan}

Asana yang dilakukan oleh anak-anak pada asana peregangan merupakan asana yang bertujuan untuk menyiapkan fisik anak menuju asana inti. Peregangan dilakukan mulai dari leher, bahu, lutut, kaki, dan meregangkan tulang belakang dalam posisi duduk dan berdiri. Asana didalam tahap peregangan ini sangat bermanfaat untuk melatih keterampilan motorik kasar anak. Keterampilan motorik kasar yang dilatih didalam asana ini adalah membantu melatih fleksibilitas anak, meningkatkan rentang gerak anak melalui gerakan sendi, meningkatkan kinerja aktivitas fisik dengan mempersiapkan otot-otot, meningkatkan 
aliran darah ke otot, memperbaiki postur tubuh, dan meningkatkan koordinasi anggota tubuh anak. Asana yang dilakukan oleh anak pada tahap peregangan ini sebagaimana yang nampak dalam gambar 2.

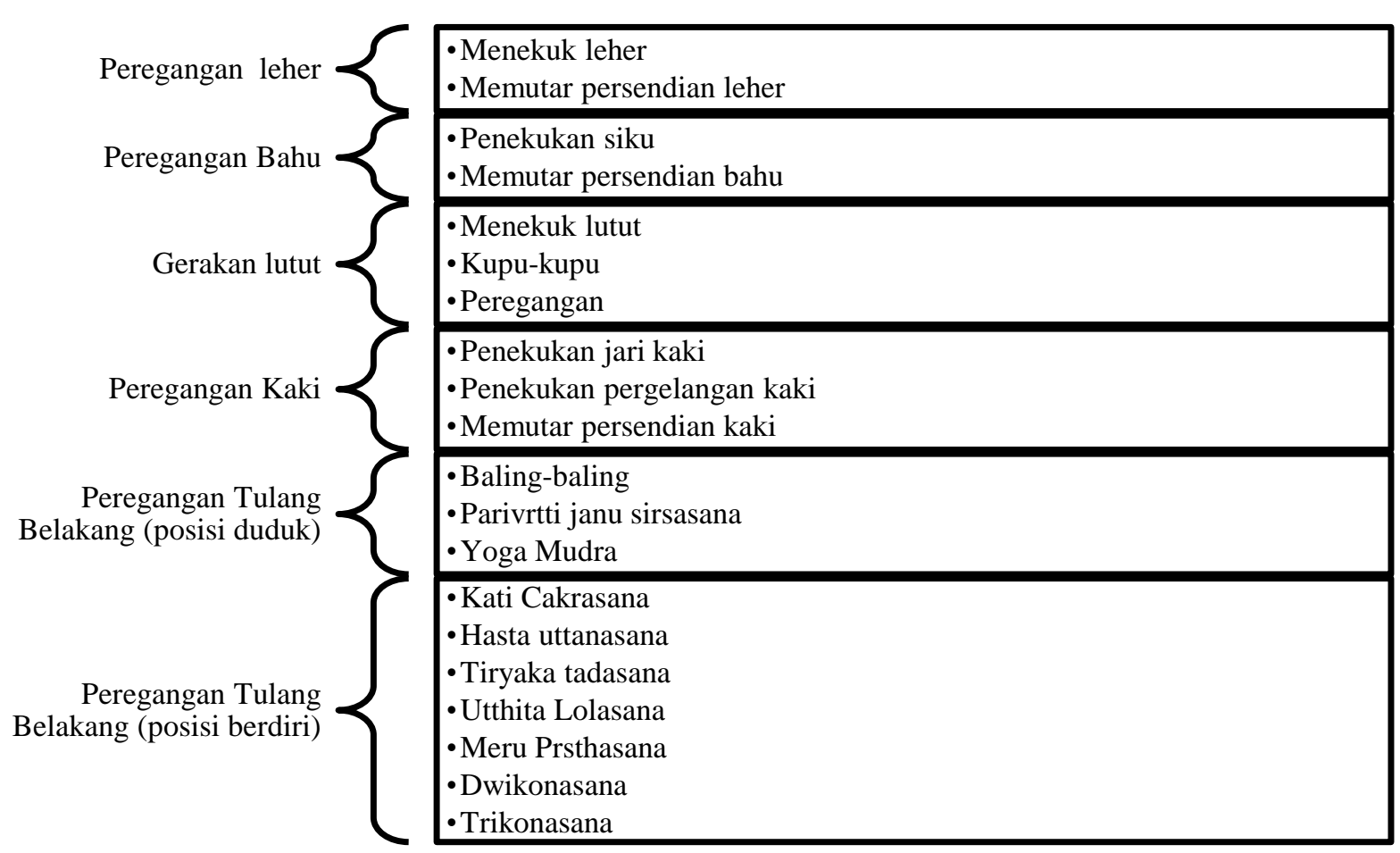

Gambar 2. Aktivitas Motorik Kasar Anak Dalam Asana Peregangan

Pada asana peregangan, terdapat enam aktivitas yang pokok yang memfokuskan peregangan pada leher, bahu, lutut, kaki, dan tulang belakang. Terdapat beberapa nama asana yang mungkin terasa asing khusus pada asana peregangan tulang belakang, baik yang dilakukan dengan duduk dan berdiri. Aktivitas motorik kasar anak pada teknik asana peregangan tulang belakang ini dijelaskan sebagaimana yang nampak pada gambar 3 . 
Jurnal PAJAR (Pendidikan dan Pengajaran)

Volume 4 Nomor 4 Juli 2020 | ISSN Cetak : 2580 - 8435 | ISSN Online : 2614 - 1337

DOI : http://dx.doi.org/10.33578/pjr.v4i5.8010

Parivrtti janu sirsasana

\section{Gambar 3. Teknik Gerakan Pada Asana Peregangan Tulang Belakang}

\section{Aktivitas Motorik Kasar Dalam Asana Inti}

Keterampilan motorik kasar cenderung dilakukan oleh anak dengan menggunakan otot besar, seperti lengan, kaki atau badan. Didalam asana inti ini, sangat banyak keterampilan motorik kasar anak yang dilatih pada 12 asana surya namaskara. Manfaat yang dapat dirasakan anak didalam asana ini berhubungan dengan otot tubuh dan syaraf terutama tulang belakang. Pada otot tubuh anak, surya namaskara dapat melatih kelenturan otot di belakang lutut, memperkuat otot lengan, punggung, perut, bahu dan kaki. Pada tulang anak, gerakan surya namaskara dapat meningkatkan kelenturan tulang belakang dan tulang leher, menyelaraskan urat-urat syaraf tulang belakang, memberikan syaraf-syaraf tersebut aliran darah yang segar, serta memperbaiki tulang belakang yang bungkuk. Selain itu, surya namaskara dapat meningkatkan koordinasi anggota tubuh anak, memperbaiki postur dan meningkatkan kelenturan tubuh anak. Asana yang dilakukan oleh anak pada tahap asana inti ini sebagaimana yang nampak dalam Gambar 4. 


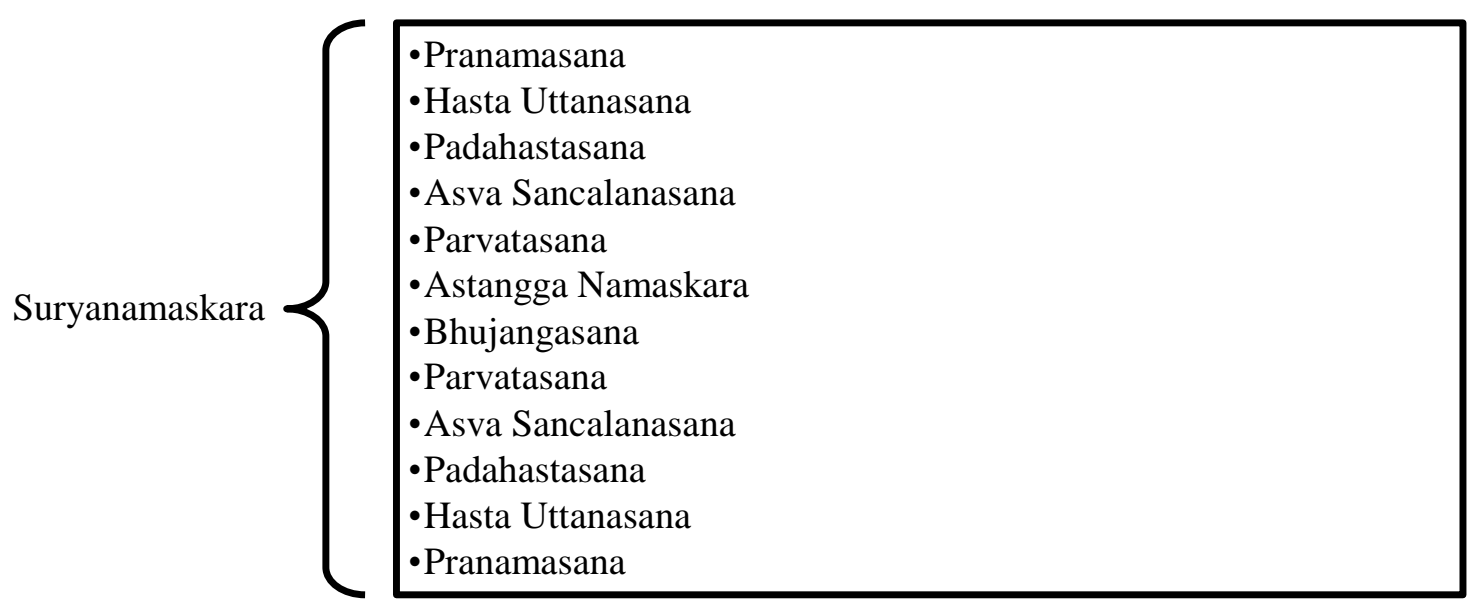

\section{Gambar 4. Aktivitas Motorik Kasar Anak Dalam Asana Inti}

Pada asana inti, dalam penelitian ini anakanak hanya diajak untuk melakukan gerakan surya namaskara. Terdapat 12 asana yang memfokuskan otot tubuh dan syaraf terutama tulang belakang. Kedua belas asana ini merupakan gerakan setengah putaran. Jadi, anak-anak diajak untuk melakukan satu pasang gerakan surya namaskara secara bergantian pada tubuh kanan dan kiri.
Dalam surya namaskara, sebenarnya gerakan yang ada hanyalah gerakan pertama hingga gerakan ke tujuh. Namun, gerakan kedelapan hingga ke dua belas merupakan gerakan yang diulang dalam setengah pasang latihannya. Aktivitas motorik kasar anak pada teknik surya namaskara ini dijelaskan sebagaimana yang nampak pada gambar 5 .

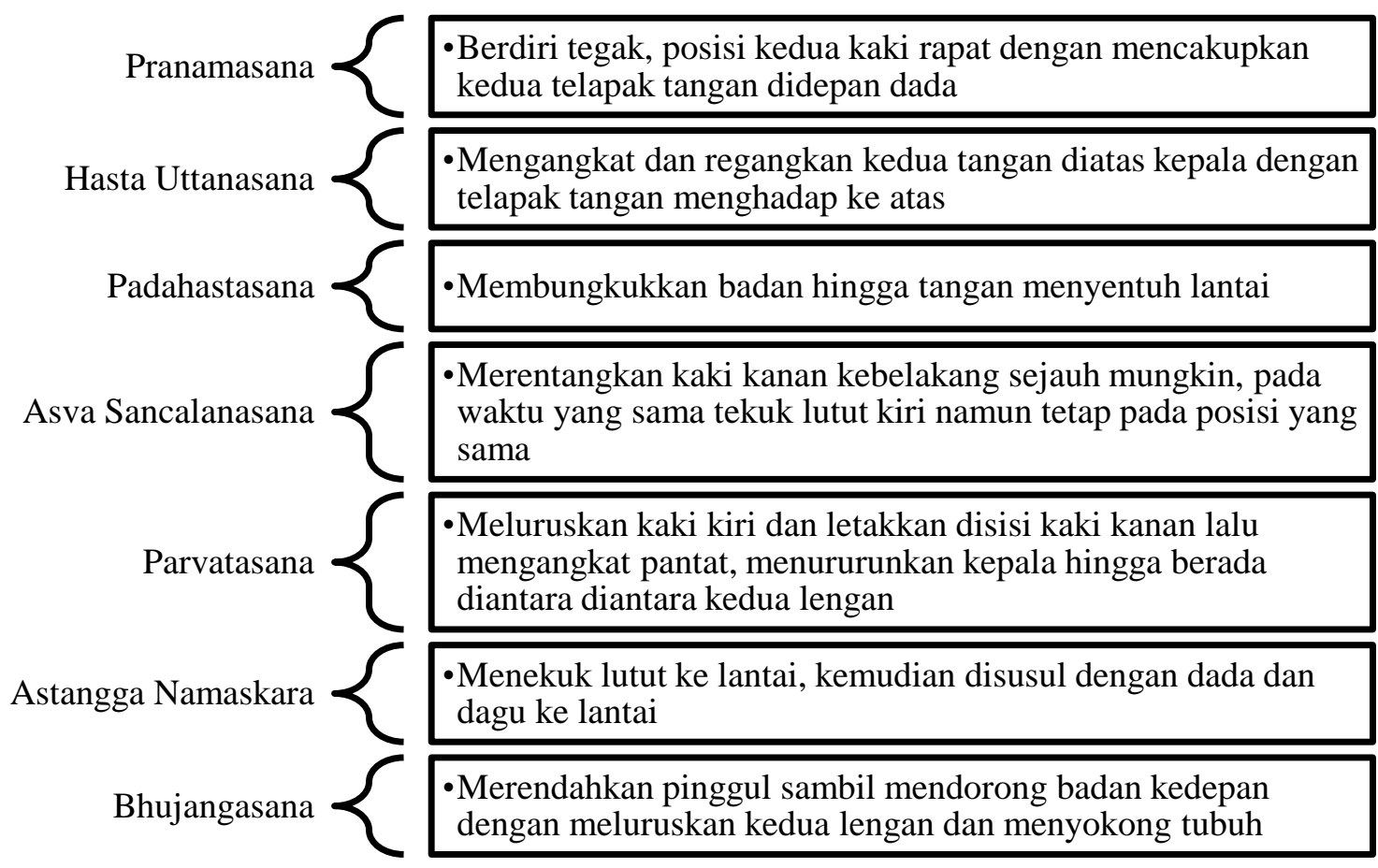

Gambar 5. Teknik Gerakan Pada Surya Namaskara 
Jurnal PAJAR (Pendidikan dan Pengajaran)

Volume 4 Nomor 4 Juli 2020 | ISSN Cetak : 2580 - 8435 | ISSN Online : 2614 - 1337

DOI : http://dx.doi.org/10.33578/pjr.v4i5.8010

Aktivitas Motorik Kasar Dalam Asana Peregangan, Pranayama, dan Meditasi

Pada tahap kegiatan asana pengendoran, pranayama, dan meditasi, tidak begitu banyak asana yang melibatkan aktifitas otot anak. Namun, pada ketiga tahap kegiatan ini, otot anak tetap dilibatkan terutama pada asana pengendoran yang bertujuan untuk merilekskan otot tubuh anak.
Pada tahap kegiatan pranayama dan meditasi, otot anak tetap beraktifitas dalam posisi silasana atau bersila yang difokuskan untuk pengaturan nafas dan ketenangan fikiran. Aktifitas yang dilakukan oleh anak pada tahap asana peregangan, pranayama, dan meditasi ini sebagaimana yang nampak dalam gambar 6 .

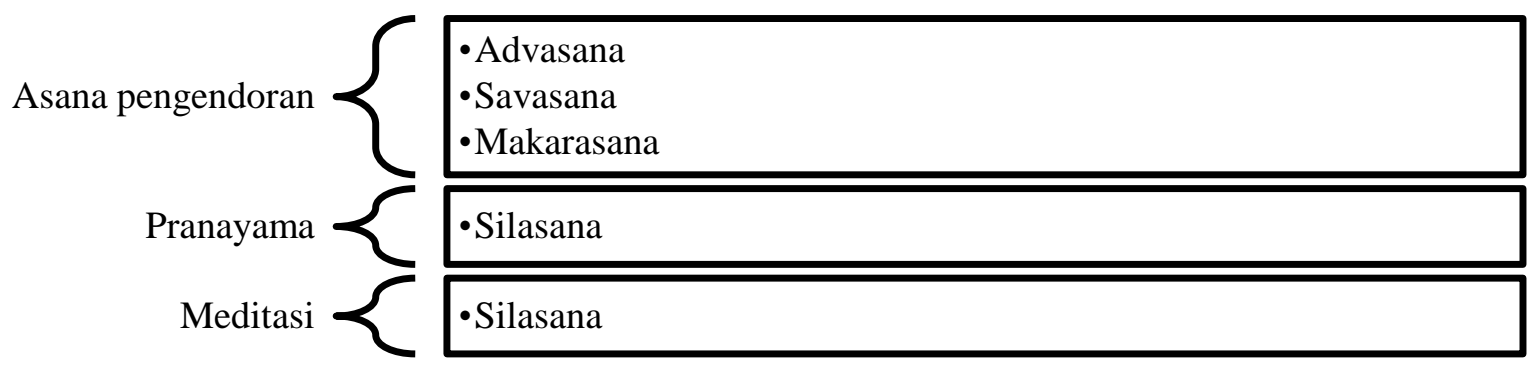

Gambar 6. Aktivitas Motorik Kasar Anak Dalam Asana Pengendoran, Pranayama, Meditasi

Didalam asana pengendoran, aktifitas motorik kasar anak tidak seperti asana peregangan ataupun asana inti. Asana pengendoran justru bertujuan untuk merilekskan otot tubuh anak setelah sebelumnya melakukan aktifitas yang cukup berat dan melelahkan. Begitu juga dengan pranayama dan meditasi. Tidak ada aktifitas motorik kasar yang berarti pada dua kegiatan ini karena fokus kegiatan ini hanya dilakukan dengan bersila. Aktivitas motorik kasar anak pada teknik asana pengendoran, pranayama, dan meditasi sederhana ini dijelaskan sebagaimana yang nampak pada gambar 7 .

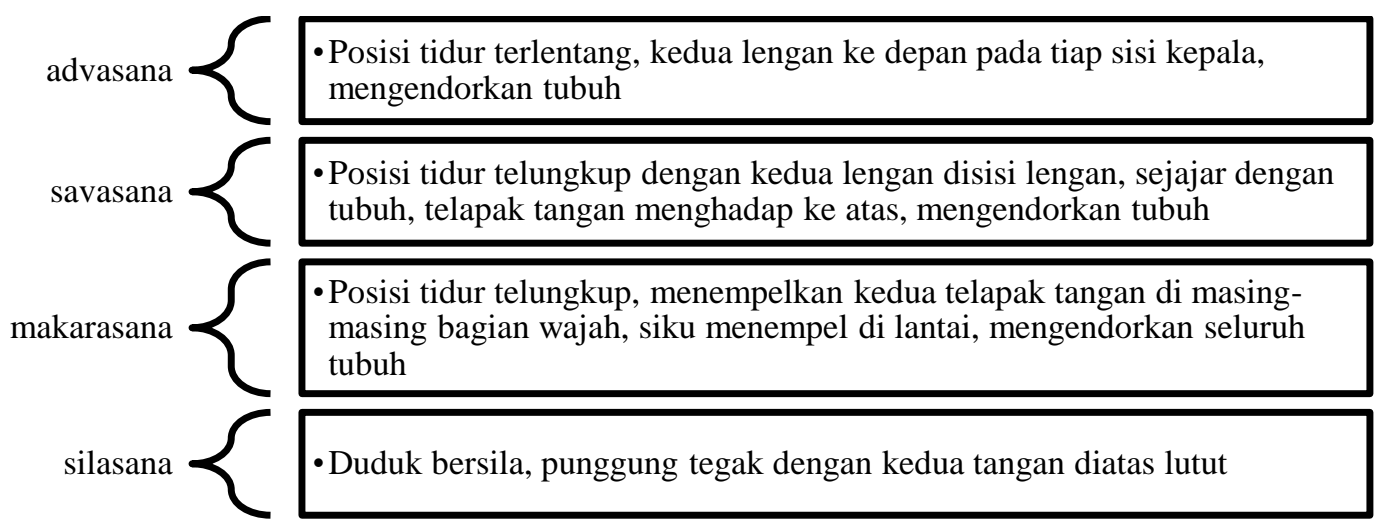

Gambar 7. Teknik Gerakan Pada Asana Peregangan, Pranayama, Dan Meditasi Sederhana

Anak-anak membutuhkan stimulasi atau pembelajaran observasional serta pengetahuan tentang hal-hal yang akan diperlukan dalam hidupnya. Pada kenyataannya, banyak orang tua yang tidak mampu mengoptimalkan potensi anakanak mereka, jadi hanya untuk dirawat secara fisik dan memberikan sejumlah asupan yang dibutuhkan oleh anak-anak, tetapi kurangnya dalam memberikan stimulasi dalam olah tubuh (Nugraha, Bayu. 2015). Ini merupakan tantangan terlebih dimasa pandemi covid-19 ini. Dengan mewabahnya virus covid-19 yang melanda hampir 
diseluruh dunia membawa hikmah terutama kepada orang tua untuk lebih memperhatikan aktivitas anak bukan hanya saja kegiatan akademiknya namun juga aktivitas fisik motoriknya. Perhatian dari orang tua ini terlebih saat aktivitas pembelajaran masih dilakukan dalam jaringan. Banyak kegiatan yang dapat dikembangkan dalam mengusir kebosanan anak dan juga kegiatan untuk memenuhi kebutuhan anak itu sendiri. Tentunya orang tua memerlukan berbagai referensi yang cukup didalam mengembangkan kegiatan dirumah untuk mengakomodasi kebutuhan anak didalam masa tumbuhkembangnya.

Hasil penelitian Nurkamelia pada tahun 2019 yang meneliti tentang perkembangan fisik motorik anak usia dini menunjukkan bahwa anak yang memiliki perkembangan fisik-motorik yang baik, ketika ia mampu mengkoordinasikan gerakan-gerakan otot tubuhnya dengan optimal. Optimalisasi gerakan-gerakan tubuh anak tentu tidak dapat terlepas dari peran lingkungan. Hal ini sejalan dengan penelitian yang dilakukan oleh Ardianti pada tahun 2019 yang meneliti tentang Tingkat Pencapaian Aspek Perkembangan Anak Usia 5-6 Tahun Berdasarkan Standar Nasional Pendidikan Anak Usia Dini. Hasil penelitian menunjukkan bahwa keberhasilan dari pencapaian standar tingkat pencapaian perkembangan anak usia dini dapat disebabkan oleh pola asuh yang diberikan oleh orangtua kepada anak, pemberian stimulasi yang sesuai dengan tingkat usia dan perkembangan anak serta faktor-faktor pendukung yang bersumber dari lingkungan sekitar anak. Pemberian stimulus berupa berbagai asana didalam setiap gerakan didalam yoga asana tentu sangat membantu mencapai optimalisasi terlebih pada keterampilan fisik motorik anak. Tidak hanya saja diperuntukkan sebagai media untuk mengembangkan keterampilan motorik bagi anakanak pada umumnya, gerakan yoga dijadikan sebagai metode intervensi bagi anak dengan ADHD untuk belajar mengendalikan gerakan, keseimbangan, serta visual-motoriknya, (P. Neva Prajna. 2017).

\section{SIMPULAN DAN REKOMENDASI}

Yoga asana dengan sistematika latihan yang berupa asana peregangan, inti, pengendoran pranayama, dan meditasi merupakan latihan yang mampu mengoptimalisasi keterampilan fisik motorik kasar anak. Manfaat yang sangat berpengaruh terhadap perkembangan motorik kasar anak adalah yoga asana dapat memperkuat otot lengan, punggung, perut, bahu dan kaki, meningkatkan kelenturan tulang belakang dan tulang leher, menyelaraskan urat-urat syaraf tulang belakang, memberikan syaraf-syaraf tersebut aliran darah yang segar, serta memperbaiki tulang belakang yang bungkuk. Orang tua, guru, dan lingkungan terdekat anak harus benar-benar memahami kalau perkembangan fisik motorik anak akan optimal apabila diberikan stimulus berupa latihan yang benar. Oleh karena itu orang tua atau guru perlu menyediakan ruang dan waktu bagi anak untuk melakukan kegiatan yang dapat melatih otot kasar anak melalui yoga asana yang berupa mengikutsertakan anak didalam ekstra kurikuler yoga asana disekolah atau latihan yoga bersama instruktur distudio yoga. Bagi komite sekolah dapat merancang kegiatan ini sebagai ekstrakurikuler wajib disekolah berserta mengundang pelatih yang kompeten sehingga kegiatan dan manfaat yoga asana semakin dirasakan oleh anak

\section{DAFTAR PUSTAKA}

Amsudin. (2008). Pembelajaran Motorik di Taman Kanak-Kanak. Jakarta: Prenada Media Grup.

Ardianti, N. (2019). Tingkat Pencapaian Aspek Perkembangan Anak Usia 5-6 Tahun Berdasarkan Standar Nasional Pendidikan Anak Usia Dini. NANAEKE Indonesian Journal of Early Childhood Education, 2(1).

Bantul. (2018). Aktivitas fisik salah satu pilar utama gerakan masyarakat hidup sehat (GERMAS).

https://puskesmas.bantulkab.go.id/bantul2/ 2018/01/08/aktivitas-fisik-salah-satu-pilarutama-gerakan-masyarakat-hidup-sehatgermas/ 
Burhaein, E. (2017). Aktivitas Fisik Olahraga untuk Pertumbuhan dan Perkembangan Siswa SD. Indonesian Journal of Primary Education, 1(1), 51-58.

Creswell, John W. (2015). Penelitian Kualitatif \& Desain Riset. Yogyakarta: Pustaka Pelajar.

Harvard Health Publishing. Introduction to yoga. https://www.health.harvard.edu/exerciseand-fitness/introduction-to-yoga.

Kompas.com. (2018) Mengenal Jenis-Jenis Yoga dan Manfaatnya Bagi Kesehatan", https://lifestyle.kompas.com/r ead/2018/04/06/110303420/mengenaljenis-jenis-yoga-dan-manfaatnya-bagikesehatan.

Nugraha, B. (2015). Pendidikan Jasmani Olahraga Usia Dini. Jurnal Pendidikan Anak, IV(1), 557-564.

Nurkamelia. (2019). Perkembangan Fisik Motorik Anak Usia Dini (Standar Tingkat Pencapaian Perkembangan Anak ) STPPA Tercapai di RA Harapan Bangsa Maguwoharjo Condong Catur Yogyakarta Kindergarten, 2(2), 112-136.

Nutriclub. (2020). Aktivitas Fisik Untuk Menunjang Kesehatan dan Kecerdasan Anak. https://www.nutriclub.co.id/articlebalita/rutinitas-anak/rutinitas-anakperilaku/aktivitas-fisik-untuk-menunjangkesehatan-dan-kecerdasan-anak.

P. Neva Prajna. (2017). Program "LARFA" untuk Meningkatkan Keterampilan Motorik Anak dengan ADHD. http://etd.repository.ugm.ac.id/penelitian/d etail/116677.

P2PTM Kemenkesri. (2018). BAGAIMANA OLAHRAGA ATAU AKTIVITAS FISIK YANG BAIK? http://kesmasid.com/bagaimana-olahraga-atau-aktivitasfisik-yang-baik/.

Puri. (2015). 3 Manfaat Yoga Untuk Anak. https://nakita.grid.id/read/023836/3manfaat-yoga-untuk-anak

Rubiyatno. (2014). PERANAN AKTIVITAS OLAHRAGA BAGI TUMBUH KEMBANG ANAK. Jurnal Pendidikan Olah Raga, 3(1), 54-64.
Saraswati, S. S. P. (2005). Patanjali Raja Yoga. Surabaya: Paramita.

Somvir. (2002). Yoga dan Ayurveda. Denpasar : Bali-India Foundation.

Sugiyono. (2006). Metode Penelitian Kuantitatif Kualitatif Dan $R \& D$. Bandung. Alfabeta.

Sujiono. B. (2010). Metode Pengembangan Keterampilan Motorik Anak Usia Dini. Jakarta: Depdikas.

Undang-Undang Republik Indonesia Nomor 20 Tahun 2003 Tentang Sistem Pendidikan Nasional.

Widyaningrum, G. L. (2020). WHO Tetapkan COVID-19 Sebagai Pandemi Global, Apa Maksudnya?.

https://nationalgeographic.grid.id/read/132 059249/who-tetapkan-covid-19-sebagaipandemi-global-apa-maksudnya. 